DOI: https://doi.org/10.34069/AI/2021.39.03.20

\title{
Academic council activity as the basis for university autonomy: historical aspect
}

\section{Діяльність вченої ради як основа університетської автономії: історичний аспект}

Received: March 2, 2021

\section{Abstract}

The article describes functions and authorities of academic councils of Ukrainian universities as the basis of their autonomy in historical aspect. The purpose of the paper is to study academic council activity evolution in Ukrainian Universities of the XIX-th century through singling out and characterization its stages from the modern standpoint to strengthen university autonomy, develop the quality of university management and prevent mistakes and shortcomings of the previous period. The applied methods were: general scientific methods (analysis, synthesis, comparison, systematization, and generalization) and methods of historical research (chronological, logical-historical, historical-typological, and retrospective). The most important findings have become distinguishing and characterizing four stages of activity of academic councils in Ukrainian universities within the studied period: I stage (1804 - 1835), II stage (1835 - 1863), III stage (1863 - 1884), IV stage (1884 - 1906). Characterization of the stages of academic council functions and authority development from the modern position has demonstrated that in order to develop the quality of university
Accepted: April 29, 2021

Written by:

Liudmyla Zelenska ${ }^{73}$

https://orcid.org/0000-0002-3324-5173

Liudmyla Holubnycha ${ }^{74}$

https://orcid.org/0000-0002-8252-9893

Tetiana Lutaieva ${ }^{75}$

https://orcid.org/0000-0002-5825-560X

Liudmyla Matsapura ${ }^{76}$

https://orcid.org/0000-0002-6509-9115

Nataliya Popova ${ }^{77}$

https://orcid.org/0000-0002-9563-0894

\footnotetext{
${ }^{73}$ Doctor of Pedagogical Sciences, Professor, Professor of the Department of Pedagogy, H. S. Skovoroda Kharkiv National Pedagogical University, Ukraine.

${ }^{74}$ Doctor of Pedagogical Sciences, Professor, Professor of the Department of Foreign Languages \#3, Yaroslav Mudryi National Law University, Ukraine.

${ }^{75} \mathrm{PhD}$, Associate Professor, Head of the Department of Pedagogy and Psychology, National University of Pharmacy, Ukraine.

${ }^{76} \mathrm{PhD}$, assistant of the Department of Language Training for foreign citizens, Kharkiv National Medical University, Ukraine.

${ }^{77} \mathrm{PhD}$, Associate Professor, Department of Foreign Languages \# 3, Yaroslav Mudryi National Law University, Ukraine.
} 
management as well as educational service quality universities need real university autonomy, which should be strong enough to prevent mistakes and shortcomings of the previous periods.

Keywords: academic council, university, university autonomy, university management, Ukraine.

\section{Introduction}

In today's world there is no doubt that education is one of the pillars of development of both the individual and society as a whole. For the most part, educational centres are associated with educational institutions and, above all, with universities, which have always played a leading role in the field of education, were considered centres of knowledge and culture, and contributed to the development of civilization.

University education has a long history, beginning with the establishment of universities in Bologna (1088), Oxford (1096 - 1117), Paris (1150) and Cambridge (1209). One of the leading principles of their qualitative functioning was the principle of university autonomy, which in our time in the Magna Charta Universitatum (2018) is listed as essential and fundamental for universities. Academic autonomy provides the right of representative collegial governing bodies to form their own strategy for the development of the educational institution, to choose priorities in teaching and research, to profile programs, to establish their own criteria for selecting faculty and admission of students, etc.

Thus, since the core of university autonomy is the issue of qualitative collegial self-government represented by academic councils, deep study and creative rethinking from the modern standpoint of historical experience (namely the finding out and studying certain stages of evolution of academic councils work, including Ukraine in the XIX century) may be significant for many spheres: firstly, the qualitative development of modern universities; secondly, as a source of enrichment of management theory and practice; thirdly, for pedagogical history; fourthly, for historical science, and finally, for studying human culture, civilization development and quality of life in general.

\section{Literature Review}

For several decades, researchers' interest in the organizational structure of universities has remained stable. In a number of scientific developments, the authors in the context of covering the genesis of higher education and university autonomy touch upon various aspects of academic councils, including the composition of academic councils (Larsson, 2020; Sahlin, 2016), redistribution of their functions and powers under current statutes (Kelleher, 2020; Larsson , 2020; Sahlin et al., 2012), the role of academic councils in solving student issues (Surcock, 2015; Zelenska, 2019), replacement of departments (Dobbins \& Knill, 2014; Enders et al., 2013), awarding scientific degrees (Kelleher, 2020; Russel, 1991) and so on.

Many researches are devoted to empirical study of academic autonomy in certain countries deliberating different aspects of relations between state and higher educational institutions in Australia (Chitra Sriayani De Silva Loku Waduge, 2011), Cambodia (Visalsok et al, 2014), Poland (Dobbins, 2015; Kwiek, 2015), Uganda (Ofoyuru et al, 2016), Ukraine (Osipian, 2017) and many other countries. Some papers consider international trends and potential problems of the phenomena under research (Agasisti et al., 2006; Christensen, 2011; Shattock, 2014).

However, not very many scientists address to historical aspects of academic autonomy (Guruz, 2011; Kohtamäki \& Balbachevsky, 2016) and surprisingly there is practically no works on historical aspects of academic councils from a modern point of view despite the importance of this issue from the position of university autonomy as well as developing qualitative university management. So our research makes an attempt to fill this gap with the example of development of the academic council activity in Ukrainian universities of the XIX century - the period of the greatest scientific interest in this area, as the formation of the national system of university education demonstrated different approaches to solving the problem of autonomy of higher education, ensuring its functioning on the basis of collegial self-government.

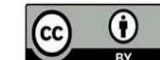


Thus, the purpose of the research is to study academic council activity evolution in Ukrainian Universities of the XIX century through singling out and characterization its stages from the modern standpoint in order to strengthen university autonomy, develop the quality of university management and prevent mistakes and shortcomings of the previous period.

\section{Methodology}

In order to reach the stated purpose the following set of methods was used:

1) general scientific methods (analysis, synthesis, comparison, systematization, generalization of legal documents, archival sources, special literature, periodicals), which made it possible to clarify the degree of research of the scientific problem, determine the source base of the study;

2) methods of historical research (chronological, logical-historical, historical-typological, retrospective), which allowed to consider the problem of research in historical retrospect, to identify the prerequisites, to determine and justify the author's periodization, development of the studied phenomenon, to characterize its features, to establish qualitative changes in its powers, functions and so on.

\section{Results and Discussion}

\section{Historical Background}

The end of the XVIII - beginning of the XIX century in the history of the peoples of Europe, was a time of crisis of the ancient regime and the transition to a new, modern era, which gradually covered all spheres of social, economic and cultural life. Therefore, the entire XIX century entered the history of the Russian Empire (part of which was then Ukraine) as a century of reforms. Education was not an exception.

The first step towards reforming the educational sphere was the creation of the Ministry of Education (1802), the next - the adoption of a special piece of legislation on the basic foundations of the new education system. For the most part, the document concerned the determination of the general professional and territorial structure of the education system. The part devoted to universities was to be supplemented by university statutes.

The main and most difficult problem facing their compilers was the question of how to implement the principle of university autonomy prevalent in Europe.

It is known that European universities were usually founded and operated under monasteries, or were private educational institutions, research and training centers for theologians, philosophers, and scholars who taught theology and research methods. In Russia, they were created on the initiative of the state and at its expense, were called Imperial and served the practical purpose of training qualified specialists for the civil service. By opening universities, the state assumed, on the one hand, responsibility for the organization, content and level of higher education, and on the other hand, undertook to ensure proper management of the educational process, through controlling its quality. This put the centralizing government in front of a choice: to introduce a system of university management similar to the German ones, in particular Göttingen, giving broad autonomy to collegial bodies, or to insist on strict university control over the trustee and minister, following the "French" model.

Thus, the nature of the management system of national universities was directly dependent on the understanding by government structures of the essence of university autonomy and the establishment of its boundaries by the state, which acted as a guarantor of the functioning of universities. The core of university autonomy was the issue of collegial self-government.

During the XIX century, universities in the study area four times - according to the number of reigns of emperors underwent reforms and counter-reforms, which were traced in the university statutes $(1804,1835$, $1863,1884)$. The issue of university autonomy was one of the most important for them. Approaches to its solution indicated that the leadership of the Russian Empire was carried out not by the aristocracy, but by the bureaucracy (Gluzman, 1997). Thus, if at the beginning of the XIX century university autonomy was perceived in the perspective of "freedom" from state leadership and control (Bagautdinova, 2003), then, according to "Temporary rules for the organization of student institutions in higher educational institutions 
of the department of the Ministry of Public Education" (1901), at the turn of the XIX - XX centuries, after a series of transitional stages, it was seen only in "election of officials with their mandatory subordination to state bodies". In view of this, approaches to the implementation of the principle of collegial selfgovernment in Ukrainian universities have undergone transformational changes.

\section{Stages of Evolution of Academic Councils}

The abovementioned requires the establishment of appropriate stages in the evolution of university collegial bodies, i.e. academic councils, whose activities were aimed at implementing the outlined principle. Paying attention to the fact that it is social, political, legal, economic, ideological processes in conjunction with pedagogical set the parameters of educational policy that serve as a foundation for the establishment of periodization (Sukhomlynska, 2002), we have identified the following criteria to justify the stages of the academic councils in national universities of the XIX century, namely:

1) features of government policy in higher education, reflected in university statutes, decrees, orders, circulars of the Ministry of Education implementation of the principles of autonomy and collegial selfgovernment in higher education;

2) the range of functions delegated to academic councils, which determined the directions of their activities;

3) the degree of development of scientific knowledge, which led to an increase in the level of professional and managerial competence of members of academic councils;

4) a system of replacement of professorships, which provided access to membership in the academic council.

The study shows that the composition, powers, activities of the academic councils of Ukrainian universities were regulated primarily by current statutes. According to the adopted statutes of the Imperial Russian Universities, we consider it necessary to distinguish four stages of formation and development of academic councils in Ukrainian universities during the XIX century, namely: I stage (1804 - 1835), II stage (1835 1863), III stage (1863 - 1884), IV stage (1884 - 1906).

Speaking about the first stage (1804-1835), we defined it as the stage of official recognition and legislative registration of the activity of academic councils. According to the results of the study, in the first quarter of the XIX century national universities operated under the statute of 1804, which absorbed the best achievements of then educational thought in the West and was based mainly on the German system of university autonomy embodied at Gottingen University. At the same time, it had some borrowings from the French and Austrian centralized higher education systems, which were more in line with the autocratic country. In practice, in addition, the experience of the Polish Education Commission, well known to Polish officials in the Russian service, was taken into account.

The statute of 1804 laid the foundations of university autonomy, which provided for the transformation of the latter into self-governed, independent of state control research and training centers. This required, firstly, the introduction of a system of collegial self-government; secondly, the election of the leadership (rectors, vice-rectors, deans); thirdly, the implementation of the principle of self-replenishment of the teaching staff by electing candidates by the board of professors without coordinating their candidacies with bureaucratic authorities; fourthly, granting freedom of research and teaching; fifthly, the protection of the educational process from the incompetent intervention of government bureaucrats (Georgiyevskiy, 1890). The implementation of the outlined tasks was complicated by the lack of practical experience in realizing the principle of collegiality of management in the national higher school. Therefore, the activities of the collegial representative body of university self-government - the Academic Council, had to be built on the basis of borrowed in the West forms and methods of interaction of universities with government agencies. Analysis of the Statute provisions of the Imperial Kharkiv University (Khodzhaev, 1945) allows us to state that the idea of collegial self-government was put into practice by the Academic Council, which consisted only of ordinary and honored professors chaired by the rector. Adjuncts (modern associate professors) had the right to be present at council meetings, but they were given the right to vote only when discussing the organization of the educational process. The composition of the council was staffed on the basis of suffrage, but required the approval of the Minister. The rector was responsible for convening the council on a monthly basis and chairing its meetings. The rector was elected from among ordinary professors for a term of one year. His candidacy was approved by the emperor at the suggestion of the Minister of Education, and only he could dismiss the rector (Vladimirskiy-Budanov, 1884). 
In terms of the problem under study, the fact that the relatively short term of office of the rector was motivated by the desire to avoid abuse of power by him is of interest. The procedure for electing the rector was also democratic - all members of the council had to run. The one who got the most "white balls" was chosen from among them. At the same time, the rector was considered "the first among equals", and his decisions and actions could be easily appealed at council meetings or in the university court.

The study shows that according to the Statute of Kharkiv University, the council was recognized as the "highest authority" in the management structure of the university. Accordingly, it was entrusted with a number of functions. In particular, the statute of 1804 assigned to the council educational, scientific, judicial-police, financial, administrative-economic and public-educational functions, which indicates a fairly wide range of activities of the university collegial body. These functions were implemented in the process of resolving current cases, as well as those that did not require regular discussion and were put on the agenda if necessary. Thus, among the current cases to be considered at the meetings of the Academic Council were: election of professors, honorary members, adjuncts, as well as approval of teachers of universities, gymnasiums, county schools, who "had certain abilities"; discussion of ways to improve the teaching of science at the university and schools of the district; approval of the order of training courses and determination of the term for their mastering; conducting annual exams for students; discussion of proposals received from the Ministry of Education and the rector of the university; making decisions on court cases submitted for consideration by the university board in accordance with the filed appeals (Khodzhaev, 1945).

In addition, special meetings of the Academic Council chaired by the Rector were to be appointed on a monthly basis, where professors and honorary members would hold discussions on scientific discoveries, research, and works. The subject of such meetings could be suggested by the rector or any of the council members. To encourage research among the teaching staff, the council annually proposed topics for competitive works with the determination of the amount of remuneration for their satisfactory solution (Voilenko, 1965).

According to the statute of 1804 , the university played the role of the leading educational institution in the district, which required from it a wide administrative and pedagogical activity. In view of this, the competences of the Academic Council were cases concerning the organization of primary and secondary schools in the district. In particular, the meetings of the Kharkiv University Council elected a school committee of 6 professors chaired by the rector, who managed the district's educational institutions, appointed visitors, heard their reports, enrolled and dismissed principals and teachers of gymnasiums and schools, reported primary and secondary schools, construction of premises for them, etc. (Voilenko, 1965). Once a year the council was obliged to consider all financial accounts signed by the cashier and accountant, on which the rector reported (Khodzhaev, 1945).

Scientific ethics requires to state that the frequency with which meetings of the Academic Council were to be convened (scheduled - once a month, extraordinary - if necessary) and a fairly wide range of its activities could not provide direct and full management of the university. In view of this, the Academic Council was only the "highest instance" to which other administrative structures were accountable, in particular for educational affairs - faculty councils; for police, financial, economic and judicial affairs - the board (Vladimirskiy-Budanov, 1884).

It is noteworthy that lack of actual experience of university self-government and stable traditions of collegial management in the Russian Empire often led to unprecedented interference of both the trustee and the Minister in the work of the academic councils, including staff appointments and administrative pressure. Moreover, after the end of the wars with Napoleon, when a new political and intellectual climate was established in Europe, abandoning the ideals of the Enlightenment and returning to traditional religious canons, administrative pressure on the work of academic councils of national universities, including Kharkiv, began to grow. The main blows were directed against the very idea of the autonomy of the scientific corporation, which was guided by its own laws and acted on the principles of collegiality and election.

The next step towards strengthening the administrative influence on the activities of academic councils was the open persecution of foreign professors who were frightened and left Kharkiv University. According to the order of the Ministry of Education, the replacement of vacant departments was to be carried out 
exclusively by Russian teachers (Georgiyevskiy, 1890). This immediately affected the activities of the Academic Council of Kharkiv University, which became "apathetic and indifferent" to the decision of university affairs.

In the 1920s, the relations of academic councils with the trustees of educational districts underwent significant changes. Thus, the trustee of the Kharkiv educational district drew up a project to reform the university management system, which aimed to limit the powers of the Academic Council. In particular, the project provided for changes in the procedure for electing the rector and deans (Kinelev, 1995). And in 1826, the trustee of the Kharkiv educational district received permission to invite professors and adjuncts to the positions independently, without the consent of the members of the Academic Council, with the subsequent approval of the Minister.

In 1830, a personal decree came into force, according to which the procedure of "appointing the rector of the university without setting a term in office" was introduced. It looked like this: the Academic Council selected 3 candidates from among its members and submitted a list of candidates to the trustee, indicating the number of votes they received. The trustee reported on the results of the vote to the Minister, who at his own discretion submitted for approval to the emperor one of the nominees (Kinelev, 1995).

In the early 1930s, the Ministry of Public Education undertook an open audit of the organizational and managerial structure of universities. So, at a meeting of the Committee of Ministers held in April 1831, for the first time there was raised a question of the need to separate the economic, financial and all administrative parts of university management from teaching with the release of members of academic councils. Instead, the functions of the university administration and the management of the educational district were designed to be transferred to the trustee (Kinelev, 1995).

In 1835, a new Statute of the Imperial Russian Universities appeared. Having acquired the status of "General", it laid the foundations for the restriction of university autonomy, the leading principles of collegial self-government, and, accordingly, the narrowing competence of academic councils. The second stage of activity of academic councils in Ukrainian universities covers the period of validity of 1835 statute (1835 - 1863) and is characterized as a stage of redistribution of academic council powers on the basis of reforming the management system of national universities. Researchers convincingly prove that the statute of 1835 reflected the changes in views on the importance of universities as educational and research institutions, the boundaries of university self-government, which have long matured in government circles (Bagautdinova, 2003; Kinelev, 1995 and others).

The concept of restructuring higher education was based on the principles of Russian statehood and culture and was embodied through the formula: "Autocracy, Orthodoxy, Nationality" and was aimed at limiting university autonomy. The statute of 1835 deprived universities of their basic public functions, including control over primary and secondary education in the educational district, the right to their own court and police, and administrative and economic activities. As a result, the functions of the Academic Council were significantly narrowed, which affected the restriction of its activities and led to the redistribution of powers between other management structures. In particular, the academic councils partially lost their educational function (Demyanenko, 2009). Only the trustee could now initiate discussions at council meetings on issues that required "educational considerations," namely: improving the teaching of science in primary and secondary schools; introduction of additional courses; use of textbooks and manuals, etc.

With the abolition of the right of universities to have their own court, academic councils lost their judicial and police functions. From now on, all students, teachers or university employees arrested by the police in case of civil offenses were subject to the power of the rector, criminal - general jurisdiction, provided the presence at court hearings of a special representative from the university (Movshovich, 1957).

As a result of the separation of the administrative part of the university from the academic, the positions of university juror, trustee in bankruptcy, secretary of the council and inspector of state-funded students which, according to the statute of 1804 , were entrusted to professors and adjuncts and approved at council meetings, were to be embraced by military or civilian officials.

In addition, dependence of the Board on the Academic Council was significantly reduced. It should be emphasized that from an executive body of the Academic Council for Economic, Police, Financial and Judicial Affairs, it became a purely economic instance. The Academic Council no longer received financial 
reports from the Board and not having information on its own budget it was removed from the distribution of material resources (Vladimirskiy-Budanov, 1884).

The provisions of the statute of 1835 no longer provided for separate meetings of the Academic Council, aimed at disseminating scientific knowledge, as well as determining the topics of competitive research papers. In this regard, the council was granted only the right to grant permission to establish scientific societies in certain fields of knowledge (Movshovich, 1957).

The system of suffrage, which was fully used by the Academic Councils during the 1804 statute, also underwent certain changes. Currently, in accordance with Art. 80 of the General Statute of the Imperial Russian Universities, not only the Academic Council, but also the Minister acquired the right to appoint professors and adjuncts to vacant departments at his own discretion. However, dismissal from these positions required mandatory approval at meetings of the Academic Council (Demyanenko, 2005).

Thus, the abovementioned gives grounds to assert that by removing from the competence of the academic councils judicial, police, financial and administrative-economic functions, the statute of 1835 limited their activities exclusively to matters of educational and scientific nature. The current cases to be decided at the council meetings included: election of the rector (for 4 years with the subsequent approval of the Minister), honorary members and correspondents, as well as professors, adjuncts and lecturers of the university; discussion of proposals for improving the teaching of sciences; distribution of training courses and determining the number of hours for their study; consideration of submissions of faculties for obtaining academic titles by candidates; analysis of shortcomings in the performance of their duties by professors; general management of educational and auxiliary institutions; approval of texts of scientific works, translations, act speeches, which were published at the expense of the university (Demyanenko, 2009).

However, as noted by researchers A. Geogiyevskiy (1890), I. Vakarchuk, Zubrytska (2002), L. Vovck (1995), despite a number of restrictive measures that led to a narrowing of the competence of academic councils, the introduction of small-scale regulation of their activities and control of the trustee, the statute of 1835 had a more favourable effect on the work of academic councils of national universities, when the "spirit of apathy and indifference" prevailed among the professors.

As we managed to find out the reasons for these were the following: firstly, the composition of the academic councils itself underwent significant renewal. In particular, new scientific forces were sent to Kharkiv University, which in the late 1930s and early 1940s created an "era of magnificent prosperity" for the teaching activities of professors devoted to science and the university, imbued with the spirit of idealism. This was achieved due to the establishment of work on the training of teaching staff for higher education institutions, the introduction of a system of research trips and internships abroad. Secondly, according to D. Bagaliy (1899), the release of professors from difficult and ungrateful financial and economic functions, as well as "public service", which fully corresponded to the general mood of members of academic councils, helped to focus on improving the educational process in higher school and intensification of research work, because the academic councils were given full responsibility in these areas.

Thus, as a result of the redistribution of powers between management structures on the basis of the statute of 1835 , in the activities of academic councils of national universities there were some positive trends, in particular in the organization of educational and research work.

However, the late 40s - early 50s of the XIX century became a time of radical changes in university policy again. Universities were deprived of all privileges, including the right to self-government. Thus, under the influence of the events of 1848 in Europe (the "Spring of the Peoples"), the Ministry of Education introduced a series of measures aimed at "protecting Russian universities from the storms that troubled neighboring states" (Movshovich, 1957). In particular, the academic councils were deprived of the right to vote, and the Minister of Public Education was given the authority to appoint rectors and deans for an indefinite period. The election of vice-rectors "by special order" was also suspended. In case of illness or absence of the rector, his place was taken by one of the deans appointed by the trustee. From 1849, the practice of foreign business trips for scientific purposes was abolished. Open lectures and public defense of dissertations have been mostly stopped. A ban was introduced on the teaching of all philosophical courses, as well as state law, political economy, Slavic studies, and so on. To strengthen oversight of university teaching, rectors and deans had to follow special instructions (Georgiyevskiy, 1890). 
The activity of scientific councils of Ukrainian universities was practically paralyzed. According to M. Vladimirskiy-Budanov (1884), they showed "inertia" in relation to university affairs. Among the reasons that led to the decline of their activities there were the following:

- Removing academic boards from reasoning and decision-making on the vast majority of issues related to the life of the university. Deprived of any responsibility for the internal organization of the university, the academic councils, instead of a "stimulating and driving basis," were characterized by "scientific stagnation" and "immature fascination with the democratic epoch of the early nineteenth century";

- Weakening the composition of scientific councils. After the closure of the professorial institute in Dorpt, the ban on inviting foreign scientists to vacant departments, the introduction of an extremely complex system of examinations for academic degrees, the professional level of teaching staff has decreased significantly. During the replacement of the departments, more often not the scientific achievements of the applicants were taken into account, but their "reliability";

- Low material security of professors, which degraded their dignity. In this regard, B. Hlynsky noted: "They increasingly turned to side jobs, seeking to improve their financial situation, and valued these side jobs more than service at the university, and even more so, work in the council, which took a lot of time" (Vladimirskiy-Budanov, 1884).

Liberalization of public life in the late 1850 s, the intensification of the student movement necessitated a radical university reform. As early as 1858 , work on the development of a new draft of the university statute began, and in December 1861 its full edition was presented. The central idea of the new statute was the autonomy of the professorial board.

The content of the project was put up for wide discussion. As such an action was not typical for the previous practice of drafting bills in the Russian Empire, it significantly intensified the work of academic councils. Councils of all national universities sent their responses to the draft of the statute. The leitmotif of these responses was the justification of the need to expand university autonomy, limit the power of the trustee and provide a decisive say in considering both scientific and educational, as well as economic and administrative issues to the professorial boards. These factors created the preconditions for a radical reform of national universities and laid the groundwork for a new step in the work of the university collegial body. The third stage (1863-1884) defined by us covers the period of validity of 1863 statute and is characterized as a stage of intensification of academic council activity and distribution of its levers of influence on all spheres of university life.

The new university statute, on the basis of which five universities of the Russian Empire operated, including Kharkiv and Kyiv (Ukraine), entered into force on June 18, 1863. According to M. Vladimirskiy-Budanov (1884), B. Glinsky emphasized that the new statute confirmed the basic principles of the statute of $1804-$ autonomy and collegial self-government. From our point of view, it is explained by the fact that in the statute of 1863 an attempt was made to clearly define the boundaries of the autonomy delegated to universities.

One of the indicators of university autonomy is the right of collegial self-government. Despite the fact that the Academic Council, as a university-wide collegial body, under the statute of 1863 acquired the status of "supreme authority" to decide not only educational but also economic, police and administrative matters and subordinated to its power other administrative structures (board, university court, Inspectorate for Student Affairs), its decisions required either the final approval of the trustee or the approval of the Minister. In this way, the authorities reserved the right to control the activities of university self-government bodies and, in particular, the Academic Council.

In accordance with the provisions of the statute of 1863, the final approval of the council was subject to matters relating to: the distribution of subjects and the order of their teaching at all faculties; awarding medals and scholarships to students; determination of awards for scientific research, which were offered to scientists on behalf of the university; approval in academic degrees and in the title of a real student; distribution of funds allocated according to the budget for the development of support and educational institutions; leaving fellows to prepare for a professorship; recommendations for the publication of scientific works; replacement of vacant departments on the basis of the announcement of the competition; approval of the annual estimate, income and expenditure of special funds of the university, as well as the decision of the university court. 
The agreement with the trustee required a decision of the Academic Council on measures to improve the scientific activity of the university; election of associate professors, lecturers, vice-rector or inspector, honorary members, judges and candidates for the university court, as well as lower staff of the university. In addition, the trustee's approval was subject to instructions issued by the council for the vice-rector or inspector and a number of rules, namely: on the procedure for collecting, distributing and using funds paid by students for tuition; admission of students to the university; admission of third parties to the lectures and the establishment of an appropriate fee; the rights and responsibilities of students and the determination of the degree of punishment for their violation; record keeping in the university court, etc.

A separate group of cases, which was within the competence of the Academic Council, was submitted to the Minister for approval through the trustee of the educational district, namely: on the election and dismissal of the rector, deans, vice-rector or inspector and professors; division of faculties into branches, unification and separation of departments, replacement of each other; business trips of young scientists abroad in order to prepare for the replacement of departments; rules on the term and procedure for conducting examinations for the award of academic degrees and titles, as well as applications for the establishment of scientific societies (Dzvinchuk, 2007).

It should be emphasized that an important feature of the new statute was the acquisition by the councils of the right to take into account regional peculiarities in resolving the cases assigned to them, but again with the permission of the trustee. This can be confirmed by the right acquired by the councils to draw up a number of rules that govern the internal regulations of the university. In addition, in order to prevent arbitrariness in the activities of academic councils, there was a requirement of accountability and publicity (Movshovich, 1957). In this regard, the minutes of the meetings of the Academic Councils, indicating the opinion of the minority began to be published after their approval by the trustee (Dzvinchuk, 2007). At the end of the year, the council compiled a full report on its activities and submitted it through a trustee to the Minister of Education. Such a report also required disclosure.

Thus, qualitative changes in the university management system, which took place on the basis of the restoration of autonomy and the right of collegial self-government by the 1863 statute, influenced the fact that "the academic board became a living body of the university, and its internal life grew and developed" (Movshovich, 1957).

After the assassination attempt on Russian Tsar Alexander II in 1866, there was a departure from the liberal direction, which was dictated by the tasks of ideological influence on society. As early as 1872, the Ministry of Public Education put on the agenda the need to radically revise the statute of 1863 . The main purpose of the new reform was to return the status of "state institution" to universities (Movshovich, 1957). In view of this, the following guidelines for reforming university education were identified: - limiting the autonomy of professorial boards with the removal of administrative and police functions from their competence; establishing a new procedure for appointing professors; - strengthening state control over teaching; restriction of access to education for poorly trained and financially disadvantaged students.

The abovementioned gives grounds to conclude that a new fourth stage (1884 - 1906) began in the activity of academic councils of Ukrainian universities - the stage of formalizing the activity of academic councils and absorbing their functions by other management structures on the basis of establishing strict state control over universities. Its lower limit is determined by the enactment of the new university statute of 1884 , and the end - attempts to reform the management of national universities, which began in the late XIX - early XX century and ended with the preparation of a new university statute in 1906.

In the course of the research it was established that the general university statute of the Imperial Russian Universities (1884), on which the universities of Ukraine worked: Kharkiv, Kyiv and Novorossiysk, significantly changed their previous national system with autonomy and suffrage. "Never before," wrote V. Buzeskul (1905), "have universities been subordinated to the government to such an extent, or more precisely to ministerial influence and control. Universities are completely dependent on the Ministry. The latter established everything, even the smallest details of their new system, appointed, promoted and dismissed professors, elected rectors, and appointed examination commissions. It reviewed and approved the review of teaching and distribution of lectures, even reaching the point that it required permission to transfer lectures from one day or hour to another..." 
If the statute of 1863 provided for the organization of the management system of national universities in accordance with the "German" model, i.e., creating conditions for its autonomous functioning, the statute of 1884 reorganized it on the French model, namely on the basis of administrative centralization. In view of this, the academic councils were completely removed from any influence on the management of the university. Their importance has significantly decreased, and the scope of competence was reduced to nothing. Thus, according to "Report of the commission, elected by the Council of the Imperial Kharkiv University, to discuss the issue of the remuneration system for university teachers, based on the collection of special fees from students and listeners for listening to lectures and for supervising their studies" (1897), the final approval of the council was now subject only to matters relating to: a) determining the total number of medals awarded to students and outsiders for scientific works; b) their distribution between individual faculties; c) approval of academic degrees.

In the first years after the promulgation of the statute, the Academic Councils of national universities, including Kharkiv, Kyiv and Novorossiysk, still participated in the discussion of drafts of certain rules and measures related to changing the articles of the previous statute, from 1886, when the new order was finally approved, their activity was limited exclusively to "current affairs", which were of a formal nature. Thus, according to the mentioned report (1897) as well as "Report of the commission elected by the Council of the Imperial Kharkiv University to answer the questions proposed by the Ministry of Public Education on changing the statute of 1884" (1901) on the activities of academic councils of Kharkiv, Kyiv, Novorossiysk universities of the late XIX century, such cases as discussion of teaching review, use of special funds of the university, applications of faculties for temporary permission to fill vacant departments, setting the amount of remuneration to associate professors were called "the most important". But, as a rule, these cases were only heard at council meetings and with a certain conclusion were transferred for final decision to the "higher instances". Therefore, among the decisions of academic councils, the most prominent were those that ended with the wording: "take note or implementation."

In terms of the problem under study, we consider it necessary to emphasize that under the statute of 1884 the power of the rector was significantly expanded. From being "first among equals," he became a government administrator, to whose authority ordinary professors were to submit, from among whom he was appointed by Minister for a term of four years. After a four-year term, the rector could be left with the Supreme Permit in this position for another term. He was declared the closest assistant to the trustee, and then left the jurisdiction of the faculty and was no longer considered its executive body. The rector was entrusted with the direct management of all departments of the university. In the event of an emergency, he acquired unlimited power, even if decisions on certain issues exceeded his official authority.

The results of the study point to the fact that the statute of 1884 gave the faculties much more independence, as a result some of the cases that were previously subject to consideration by the Academic Council were transferred to the faculty meetings. Thus, the cases that from that moment were subject to the final decision of the faculties included: conducting tests for academic degrees, semi-course and final exams; providing graduation certificates to persons who had completed a full course; adoption of resolutions on permission to give lectures to masters with the rank of associate professors; consideration of scientific works recommended for publication at the expense of the university; determination of the list of annual tasks for students and external listeners for obtaining medals and prizes; discussion of the rector's proposals to improve university teaching; consideration of teachers' reports on the course of practical classes; granting permission to doctors of foreign universities to take exams for a master's degree, etc. The faculties only informed the academic council about the outlined issues, and their decisions were submitted through the trustee for approval by the Minister.

However, according to "Report of the commission, elected by the Council of the Imperial Kharkiv University, to discuss the issue of the remuneration system for university teachers, based on the collection of special fees from students and listeners for listening to lectures and for supervising their studies" (1897), a number of issues still required approval by the academic council of the university, namely: proposals of individuals to fill the vacancies of professors and lecturers; the decision to award a degree to persons who had met the requirements; application for a doctorate to persons who were known for their scientific work, but had not prepared the relevant dissertations; curricula and review of teaching with distribution of lectures and practical classes; proposals for the reorganization of departments, admission to exams and procedures for their conduct, remuneration to private associate professors, distribution of funds intended for the expansion of support and educational institutions of individual faculties, etc. 
Thus, the statute of 1884 effectively annulled the independence of the academic councils, giving it the role of "executive body" in relation to the orders of the Ministry of Education and the "coordinating authority" through which the faculties communicated with the trustee and the Minister. Academic councils acquired the character of an advisory body, which discussed all the most important issues of the organization of university education, but this body did not have any direct administrative or legislative functions.

\section{Conclusions}

The conducted historical and pedagogical analysis allowed distinguishing and characterizing four stages of activity of academic councils in Ukrainian universities within the studied period:

The first stage (1804-1835) was the official recognition and legislative registration of the activities of academic councils. The peculiarity of this stage was the development of the regulatory framework that controlled the mechanism of creation and operation of academic councils. Characteristic features of this stage were manifested in outlining the composition of academic councils, defining their functions (educational, scientific, administrative and economic, financial, judicial and police, public education), standardization of methods of interaction with other management structures, establishing the degree of control and accountability to state power. However, despite the broad autonomy delegated by the statute of 1804 to national universities, opened in sub-Russian Ukraine, the academic councils failed to fully implement the principle of collegial self-government during the first stage of their activities. In the second decade of the nineteenth century, academic councils underwent a series of administrative measures due to changes in the political and ideological course of the state, the strengthening of centralizing tendencies, which led, firstly, to direct government intervention in the work of academic councils; secondly - the weakening of the scientific and professional level of their personnel; thirdly, the emergence of a "spirit of apathy and indifference" among council members in resolving university affairs.

The second stage $(1835$ - 1863) was the redistribution of powers of academic councils on the basis of reforming the management system of national universities. During this stage, the activity of the academic councils in Ukrainian universities was not constant, but resembled a kind of curve. Under the influence of political, ideological, socio-economic, pedagogical factors in the second half of the 1830s - mid 1840s, despite a number of administrative measures that led to a narrowing of the functions of academic councils, their activities were characterized by fairly high productivity, in particular in the questions as for the organization of educational and scientific work. During the reaction period (late 1940s and mid-1950s), as a result of the abolition of university autonomy, the work of academic councils was practically paralyzed and marked by inertia and "stagnation." However, the processes of liberalization of university life in the late 1850 s - early 1860 s, ensuring the renewal of staff, revived the work of academic councils, especially in the direction of creating a new legal framework for qualitative university education, the guiding principles of which were autonomy and collegial self-government.

The third stage $(1863-1884)$ - the intensification of the qualitative activities of scientific councils and the spread of the levers of their influence on all spheres of university life. The activity of the scientific councils of Ukrainian universities during the third stage, as in the previous stages, turned out to be abrupt. Thus, during the second half of the 1860s, it was characterized by extreme intensity, quality and productivity, as it was the university collegial bodies during this period that were fully responsible for the capacity of universities. Despite the fact that universities remained public institutions, and thus maintained accountability and control of collegial governing bodies of government, the adoption of the leading principles of university autonomy, delegated by the statute of 1863, ensured the return to the competence of academic councils, in addition to educational, scientific and economic functions police as well as judicial ones, and the restoration of their status as "the highest authority in the structure of university administration."

The fourth stage (1884 - 1906) - the formalization of academic councils and the absorption of their functions by other governing structures - can be described as a double one, during which, on the one hand, due to increased state centralization and abolition of university autonomy, academic councils were removed from university governing and their functions were redistributed among other management structures, and on the other hand, an attempt was made to modernize the management system of national universities on the basis of delegating a wide range of functions to academic councils. 
Characteristic features of this stage were the alienation of financial, economic and judicial functions of academic councils, their loss of independence in decision-making, even on educational and scientific issues, accountability and control of the trustee and the Minister, deprivation of the right to self-replenishment, which led to formalization of academic councils, their correspondence with government agencies, which significantly slowed down decisions on the most important and sometimes urgent issues of the organization of university life.

Thus, characterization of the stages of academic council activity development from the modern standpoint has demonstrated that in order to develop the quality of university management as well as educational service quality universities need university autonomy, which should be strong enough to prevent mistakes and shortcomings of the previous periods.

\section{Bibliographic references}

Agasisti, T., \& Catalano, G., (2006). Governance models of university systems towards quasi-markets? Tendencies and perspectives: a European comparison. Journal of Higher Education Policy and Management, 28(3), 245-262. Recovered from https://doi.org/10.1080/13600800600980056

Bagaliy, D.I. (1899). Materials for the history of Kharkov University opened in the Archives of the Ministry of Public Education: a report on the trip. Kharkiv: University typography.

Bagautdinova, N.G. (Ed.). (2003). Higher school today and tomorrow: ways to overcome the crisis. Moscow: Economics. Recovered from https://kpfu.ru/docs/F943458841/6_Vsholl.pdf

Buzeskul, V.P. (1905). The history of Kharkov University under the statute of 1884 (from 1884 to 1905). Kharkiv: University typography.

Christensen, T., (2011). University governance reforms: potential problems of more autonomy? Higher Education, 62 (4), 503-517.

Demyanenko, N.M. (2005). University autonomy: retrospective, modernization: Retrospective logicalsystem analysis of the development of the autonomy principle in the management of Ukrainian universities taking into account European trends, features of the general statutes of the imperial universities 1804, 1835, 1863, 1884. Higher Education of Ukraine, 2, 42-49.

Demyanenko, N.M. (2009). World interpretation of the idea of the university: methodology, theory, implementation experience. Higher education of Ukraine, 1, 60-66.

De Silva LokuWaduge, C. (2011). Governance and Performance: an Empirical Study of Australian Universities (Ph.D. thesis). School of Law, Victoria University, Melbourne.

Dobbins, M., Knill, C., (2014). Higher Education Governance and Policy Change in Western Europe: International Challenges to Historical Institutions. London: Palgrave Macmillan.

Dobbins, M., (2015). Exploring the governance of Polish public higher education: balancing restored historical legacies with Europeanization and market pressures. European Journal of Higher Education, Vol 5(1), 18-33. Recovered from https://doi.org/10.1080/21568235.2014.969289

Dzvinchuk, D.I. (2007). Modern tendencies of development and management of education (Ph.D. thesis). Acadtmy of Pedagogical Sciences of Ukraine, Institute of Higher Education, Kyiv.

Enders, J., Boer, H. \& Weyer, E. (2013). Regulatory autonomy and performance: The reform of higher education re-visited. Higher Education, 65, 5-23. Recovered from https://doi.org/10.1007/s10734-0129578-4

Georgiyevskiy, A. A (1890). Short historical sketch of government measures and plans against student riots. Saint Petersburg: Typography of V.S. Balashova.

Gluzman, A. V. (1997). Trends in the development of university pedagogical education in Ukraine (Doctor of Pedagogical Sciences Thesis). Acadtmy of Pedagogical Sciences of Ukraine, Institute of Pedagogical and Psychological Professional Education, Kyiv.

Guruz, K. (2011). University Autonomy and Academic Freedom: A Historical Perspective. International Higher Education, 63, 13-14. Recovered from https://doi.org/10.6017/ihe.2011.63.8549

Kelleher, M. F. (2020). The Effectiveness of Governing Bodies. OESD Seminar on Governing bodies of higher education institutions: Roles and responsibilities. OECD. Recovered from https://www.oecd.org/education/imhe/Effectiveness\%20of\%20GBs.pdf

Kinelev, V.G. (Ed. ). (1995). Higher education in Russia: Essay on history until 1917. Moscow: NII VO. Khodzhaev, A.M. (1945). Higher school: Basic regulations, orders and instructions. Moscow: Soviet Science.

Kohtamäki, V., \& Balbachevsky, E. (2016). University autonomy from past to present. In E. Pekkola et al. (Eds.), Theoretical and Methodological Perspectives on Higher Education Management and 
Transformation (179-193). Tampere: Tampere University Press. Recovered from https://core.ac.uk/download/pdf/250167785.pdf

Kwiek, M. (2015). The unfading power of collegiality? University governance in Poland in a European comparative and quantitative perspective. International Journal of Educational Development, 43, 77-89. Recovered from http://unesco.amu.edu.pl/kwiek/pdf/Kwiek_Collegiality_IJED_2015.pdf

Larsson, A. (2020). Key note Address. OESD Seminar on Governing bodies of higher education institutions: Roles and responsibilities. OECD. Recovered from http://www.oecd.org/education/imhe/37378242.pdf

Magna Charta Universitatum (2018). Observatory Magna Charta Universitatum. Recovered from http://www.magna-charta.org/magna-charta-universitatum/read-the-magna-charta/the-magna-charta Movshovich, M.I. (1957). Higher school: Basically regulations, orders and instructions. Moscow: Soviet Science.

Osipian, A., (2017). University autonomy in Ukraine: Higher education corruption and the state. Communist and Post-Communist Studies, 50(3), 233-243. Recovered from https://doi.org/10.1016/j.postcomstud.2017.06.004

Ofoyuru, D.T., Lukwago, R., \& Kimoga, J. (2016). Extent of Institutional Autonomy in Determination of Content and Quality of University Education in Uganda. International Research in Higher Education, 1(2), 64-71. Recovered from http://dx.doi.org/10.5430/irhe.v1n2p64

Russel, C. (1991). Academic freedom. New York: Routledge.

Sahlin, K., Stensaker, B., Välimaa, J., \& Sarrico, C. (2012). The interplay of organizing models in higher education: What room is there for collegiality in universities characterized by bounded autonomy? Managing Reform in Universities: The dynamics of culture, identity and organizational change (198-221). London: Routledge.

Sahlin, K. \& Eriksson-Zetterquist, U. (2016). Collegiality in modern universities - the composition of governance ideals and practices. Nordic Journal of Studies in Educational Policy, 2, 1-10. Recovered from https://doi.org/10.3402/nstep.v2.33640

Shattock, M. (2014). Autonomy, self-government and the distribution of authority. M. Shattock (Ed.), International trends in university governance (184-198). London: Routledge.

Sukhomlynska, O.V. (2002). Periodization of pedagogical thought in Ukraine: steps to a new dimension. O.V. Sukhomlynska (Ed.), Development of pedagogical and psychological sciences in Ukraine, 19922002: collection (37-54). Kyiv: Academy of Pedagogical Sciences of Ukraine.

Surcock, A. (2015). Trends 2015: Learning and teaching in European universities. European University Association. Recovered from https://eua.eu/downloads/publications/trends\%202015\%20learning\%20and\%20teaching\%20in\%20europe an\%20universities.pdf

Vakarchuk, I., Zubrytska, M. (2002). Halfway to academic independence: Autonomy and social responsibility of universities. Higher education of Ukraine, 2, 58-63.

Visalsok, T., Ngoy, M., \& Virak, Y. (2014) Governance reforms in higher education: A study of institutional autonomy Cambodia. N.V. Varghese, M. Martin, M. (Eds.), Governance reforms in higher education: A study of institutional autonomy in Asian countries (120-141). Paris: IIEP.

Vladimirskiy-Budanov, M.F. (1884). Fiftieth anniversary of the Imperial University of St. Vladimir, 18341884: speech delivered at the jubilee act of the university by ordinary professor M.F. Vladimirsky-Budanov. Kyiv: Typography of Imperial University of St. Vladimir.

Voilenko, E.I. (Ed.). (1965). Higher School. Part 1. Collection of basic decrees, orders and instructions. Moscow: Higher school.

Vovck, L.P. (1995). Genesis of priority tendencies of adult education in Ukraine (second half of the XIX 20s of the XX century) (Doctor of Pedagogical Sciences Thesis). M.P. Dragomanova Ukrainian State Pedagogical University, Kyiv.

Zelenska, L. (2019). Activities of scientific councils of Universities of Ukraine of the XIX Century on the settlement of the issue of visiting ste stedn. Academic Councils in the System of Work of Ukrainian Universities of the XIXth Century. Recovered from https://www.researchgate.net/publication/330764435_DIALNIST_UCENIH_RAD_UNIVERSITETIV_U KRAINI_XIX_STOLITTA_Z_UREGULUVANNA_PITANNA_VIDVIDUVANNA_STUDENTAMI_L EKCIJ 